Afifah Nur Shobah, Swastika Oktavia. (2019). Efek Penambahan Limbah Lokal Jerami dan Sekam Padi Bagi Pertumbuhan Jamur Tiram Putih (Pleurotus Ostreatus). Journal Bioeksperimen. Vol. 5 (2) Pp. 70-76. Doi: 10.23917/ bioeksperimen.v5i2.2795

\title{
EFEK PENAMBAHAN LIMBAH LOKAL JERAMI DAN SEKAM PADI BAGI PERTUMBUHAN JAMUR TIRAM PUTIH (PLEUROTUS OSTREATUS)
}

\author{
Afifah Nur Shobah ${ }^{1^{*}}$, Swastika Oktavia ${ }^{2}$ \\ ${ }^{1}$ Jurusan Farmasi, Sekolah Tinggi Ilmu Kesehatan Salsabila \\ Jl. Raya Serang Pandeglang No.33 (PAL-6), Kemanisan, Curug, Kota Serang, Banten \\ ${ }^{2}$ Program Studi Biologi, Fakultas Sains, Farmasi dan Kesehatan, Universitas Mathl'ul Anwar \\ J1. Raya Labuan Km.23, Cikaliung, Saketi, Pandeglang, Banten \\ *E-mail korespondensi: afifahnurshobah665@gmail.com \\ Paper diterima : 9 November 2018, Paper publish : September 2019
}

\begin{abstract}
White oyster mushroom (Pleurotus ostreatus) is a group of microscopic fungi that are used as food. P. ostreatus is cultivated in an artificial medium derived from sawdust and has been sterilized. However, the use of sawdust also has problems. Straw and husk of rice can be used as mushroom growing media because they contain organic ingredients such as cellulose, hemicellulose, and lignin. This study aimed to know the growth of white oyster mushroom (P. ostreatus) on straw and husk of rice as an artificial medium and to know the best composition of straw and husk of rice that can be got highly produced of white oyster mushroom (P. ostreatus). The methods of this research were experimental with ten treatments and included several stages including preparation of tools, materials and research sites, the stage of cultivation of $P$. ostreatus and data collection. This study used an experimental method with a completely randomized design consisting of 40 experimental units. The results obtained were the most optimal P. ostreatus mycelium growth in K1J2S1 treatment with a mean growth rate of 30,60 cm / 30 days, the highest wet weight was K3J1SO which was 85,83 g while the highest dry weight was in K1J2S1 treatment that is equal to $8,71 \mathrm{~g}$.
\end{abstract}

Keywords: Pleurotus ostreatus, straw, husk, cultivation, growth

\section{Pendahuluan}

Jamur tiram putih (Pleurotus ostreatus) merupakan kelompok jamur makroskopis yang dapat dimanfaatkan sebagai bahan pangan. dan bahan obat. Menurut Nasreen et al. (2016), cendawan yang dapat dimakan (edible mushrooms) memiliki kandungan nutrisi yang tinggi. Cendawan mengandung asam amino, asam lemak, dan karbohidrat (Egra et al., 2018) yang dibutuhkan bagi tubuh manusia. Sebagai bahan obat, tiram putih (P. ostreatus) bermanfaat sebagai antikolesterol (Aryantha et al., 2010), antitumor (Facchini et al., 2014), antikanker (Wu et al., 2011), antioksidan (Jayakumar et al., 2011), antibakteri dan antifungi (Hearst et al., 2009). Menurut Widyastuti dan Tjokrokusumo
(2008), jamur tiram putih (P. ostreatus) sudah banyak dibudidayakan di lingkungan masyarakat khususnya di pedesaan. Menurut Widiwurjani (2010), jamur tiram putih (P. ostreatus) dapat dibudidayakan dalam suatu media buatan yang berasal dari kayu atau bahan lignin yang telah lapuk dan tersimpan dalam plastik yang telah disterilkan. Penggunaan media jamur tiram putih (P. ostreatus) sebagai substrat untuk pertumbuhan yang sudah lama dikenal ialah serbuk kayu. Akan tetapi, peningkatan jumlah pembudidayan jamur tiram menyebabkan ketersediaan serbuk kayu menjadi terbatas, sehingga perlu dilakukan penyediaan bahan alternatif serbuk kayu untuk budidaya jamur tiram. Jamur tiram juga dapat tumbuh pada berbagai macam media yang merupakan limbah hasil pertanian, sehingga 
limbah pertanian tidak terbuang percuma dan mempunyai nilai tambah. Limbah pertanian yaitu jerami padi dan sekam padi $y$ ang tersedia cukup melimpah. Kandungan nutrisi dalam 100 g jerami padi terdiri dari selulosa 29,63\%, hemiselulosa $17,11 \%$ dan lignin $12,17 \%$. Limbah sekam padi merupakan sumber bahan baku berserat dengan komposisi utama 33\%-44\% selulosa, 19\%-47\% lignin, 17\%-26\% hemiselulosa dan silika 13\% (Sipahutar, 2010).

Banyaknya limbah pertanian yang ada di daerah Desa Mekarsari Kecamatan Panimbang Kabupaten Pandeglang dan belum termanfaatkan, maka perlu dilakukan optimalisasi pemanfaatan limbah jerami dan sekam padi. Selain itu, berdasarkan penelitian Hariadi (2013) bahwa substrat alternatif untuk budidaya jamur untuk meningkatkan produktivitasnya dapat berupa jerami padi. Penelitian lain tentang penggunaan substrat alternatif bagi pertumbuhan jamur tiram putih (P. ostreatus) yaitu berupa serabut kelapa oleh Saidu dan Yuzir (2011). Hasil penelitian menunjukkan bahwa pada serabut kelapa juga terdapat pertumbuhan miselium jamur tiram putih (P. ostreatus). Selnjutnya penggunaan sekam padi dan daun pisang kering sebagai substrat pertumbuhan jamur tiram putih (P. ostreatus) telah dilakukan oleh Suparti dan Marfuah (2015). Sehingga pemanfaatan sekam padi dan jerami padi dapat digunakan sebagai bahan pelengkap substrat jamur tiram putih (P. ostreatus).

Tujuan dari penelitian ini adalah mengetahui pertumbuhan jamur tiram putih (P. ostreatus) pada media jerami dan sekam padi, dan mengetahui jenis media jerami padi, dan sekam padi yang menghasilkan pertumbuhan jamur tiram putih (P. ostreatus) paling baik.

\section{Metode Penelitian}

Penelitian ini meliputi beberapa tahapan antara lain tahap persiapan alat, bahan dan tempat penelitian, tahap budidaya jamur tiram dan tahap pengumpulan data. Tahap persiapan alat, bahan dan tempat meliputi mempersiapkan alat dan bahan yang akan digunakan dalam proses budidaya. Tahap budidaya jamur terdiri atas tahap persiapan media tanam jamur (baglog), pengayakan, pencampuran bahan, pengomposan, pembuatan baglog, sterilisasi, inokulasi bibit, inkubasi (pertumbuhan miselium), budidaya, perawatan dan pemanenan. Tahap pengumpulan data meliputi pengukuran pertumbuhan miselium pada baglog, pengukuran berat basah jamur tiram, dan pengukuran berat kering.

Penelitian ini dilaksanakan pada bulan Maret sampai dengan Oktober 2018 di tempat Pembudidayaan Jamur Citra Abadi yang berlokasi di Kampung Tarikolot, Desa Mekarsari, Kecamatan Panimbang, Kabupaten Pandeglang, Provinsi Banten, dan Laboratorium Terpadu, Fakultas Sains dan Farmasi Universitas Mathla'ul Anwar, Banten. Metode yang digunakan pada penelitian ini yaitu eksperimental. Rancangan dalam penelitian ini menggunakan Rancangan Acak Lengkap (RAL), terdapat 10 macam perlakuan (Tabel 1) dengan 4 kali ulangan, sehingga total perlakuan yang dicobakan sebanyak 40 unit. Parameter utama yang diamati adalah laju pertumbuhan miselium pada berbagai jenis media. Parameter pendukungnya yaitu bobot basah miselium dan bobot kering miselium. Pengukuran parameter pertumbuhan meliputi kecepatan pertumbuhan miselium dilakukan setiap 3 hari sekali, penimbangan bobot basah dilakukan setelah terbentuk tubuh buah setiap 3 hari sekali, dan penimbangan bobot kering selama 30 hari.

Tabel 1. Kombinasi perbandingan jenis media

\begin{tabular}{cccc}
\hline \multirow{2}{*}{ Perlakuan } & \multicolumn{3}{c}{ Perbandingan Jenis media } \\
\cline { 2 - 4 } & $\begin{array}{c}\text { Serbuk } \\
\text { kayu (K) }\end{array}$ & $\begin{array}{c}\text { Jerami } \\
\text { padi (J) }\end{array}$ & $\begin{array}{c}\text { Sekam padi } \\
\text { (S) }\end{array}$ \\
\hline K2J1S1 & 2 & 1 & 1 \\
K1J2S1 & 1 & 2 & 1 \\
K1J1S2 & 1 & 1 & 2 \\
K3J0S1 & 3 & 0 & 1 \\
K2J0S2 & 2 & 0 & 2 \\
K1J0S3 & 1 & 0 & 3 \\
K3J1S0 & 3 & 1 & 0 \\
K2J2S0 & 2 & 2 & 0 \\
K1J3S0 & 1 & 3 & 0 \\
K4J0S0 & 4 & 0 & 0 \\
\hline
\end{tabular}

$0: 0 \mathrm{~g} ; 1: 250 \mathrm{~g} ; 2: 500 \mathrm{~g} ; 3: 750 \mathrm{~g} ; 4: 1.000 \mathrm{~g}$ 


\section{Alat}

Alat yang digunakan meliputi cangkul, sekop, gerobak dorong, kompor, sendok bibit, centong, kantong plastik tahan panas, karet, kapas, cincin plastik, lampu spiritus, alkohol $70 \%$ dan keranjang.

\section{Bahan}

Bahan yang digunakan yaitu sebuk kayu, jerami padi, sekam padi, bekatul, kapur $\left(\mathrm{CaCO}_{3}\right)$, gips $\left(\mathrm{CaSO}_{4}\right)$, biji jagung, glukosa, dan bibit jamur tiram (P. ostreatus).

\section{Analisis Data}

Data yang diperoleh kemudian dianalisis dengan dengan analisis One Way Anava, apabila terdapat beda nyata dilanjutkan dengan uji DMRT (Duncan Mean Range Test) dengan program IBM SPSS Statistics 22.

\section{Hasil dan Pembahasan}

Miselium jamur tiram putih dapat tumbuh pada media tanam (baglog) yang dibuat sesuai dengan rancangan penelitian yaitu pada baglog berisi serbuk kayu saja, baglog berisi campuran serbuk kayu dengan sekam padi, baglog berisi campuran serbuk kayu dengan jerami dan baglog berisi campuran serbuk kayu, jerami dan sekam padi. Sharma et al. (2013) menyatakan bahwa, pertumbuhan miselium merupakan langkah awal yang menciptakan kondisi internal yang cocok untuk menghasilkan tubuh buah sehingga pertumbuhan miselium merupakan faktor penting dalam budidaya jamur. Menurut Wahidah dan Saputra (2015), pertumbuhan miselium yang cepat disebabkan karena nutrisi (unsur hara) di dalam media tercukupi. Bahan organik yang mengandung selulosa dan lignin dalam jumlah besar dapat mendukung pertumbuhan miselium dan perkembangan tubuh buah jamur.

Hasil pengamatan terhadap laju pertumbuhan miselium jamur tiram putih $(P$. ostreatus) menunjukkan bahwa tidak terdapat beda nyata dari semua perlakuan. Pertumbuhan miselium paling cepat terdapat pada perlakuan K1J2S1 dengan kecepatan pertumbuhan
$30,60 \mathrm{~cm} / 30$ hari (Gambar 1). Rerata kecepatan pertumbuhan miselium jamur tiram putih menunjukkan hasil yang tidak berbeda nyata antar perlakuan.

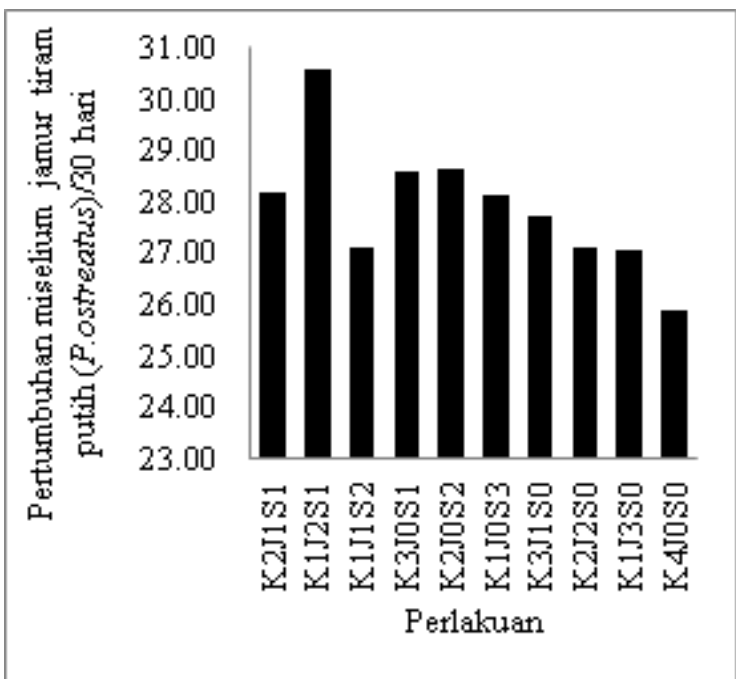

Gambar 1. Pertumbuhan miselium jamur tiram putih (P. ostreatus) selama 30 hari

Setelah pertumbuhan miselium, maka fase berikutnya adalah pembentukan tubuh tubuh jamur tiram putih (P. ostreatus). Hasil pengamatan terhadap pertumbuhan tubuh buah dapat diperoleh dari mengukur berat basah dan berat kering tubuh buah. Berat basah jamur tiram tertinggi terdapat pada perlakuan K3J1S0 yaitu sebesar 85,83 g. Rerata berat basah terendah terdapat pada perlakuan K1J3S0 yaitu sebesar 71,85 g (Gambar 2). Hasil analisis menunjukkan bahwa berat basah tubuh buah jamur tiram putih (P. ostreatus) menunjukkan bahwa tidak terdapat beda nyata antar perlakuan.

Hasil pengamatan terhadap berat kering jamur tiram menunjukkan bahwa terdapat beda nyata dari perlakuan K1J2S1 terhadap semua perlakuan. Rata-rata berat kering jamur tiram tertinggi terdapat pada perlakuan K1J2S1 yaitu sebesar 8,71 g. Rata-rata berat kering terendah terdapat pada perlakuan K1J1S2 yaitu sebesar 5,09 g (Gambar 3).

Lama pertumbuhan miselium jamur tiram putih (P. ostreatus) pada baglog merupakan salah satu indikator keberhasilan inokulasi. Miselium yang tumbuh dalam media juga membutuhkan 
nutrisi bagi pertumbuhannya supaya dapat tumbuh dengan optimal. Komposisi media antara serbuk kayu, sekam padi dengan jerami padi mengandung selulosa, lignin, hemiselulosa, serta unsur hara yang baik bagi pembentukan miselium dan pinhead. Serbuk kayu, sekam padi dan jerami padi dapat terurai menjadi partikel yang lebih sederhana yang dapat digunakan untuk hifa jamur tiram putih (P. ostreatus) dalam menyerap nutrisi untuk pertumbuhan.

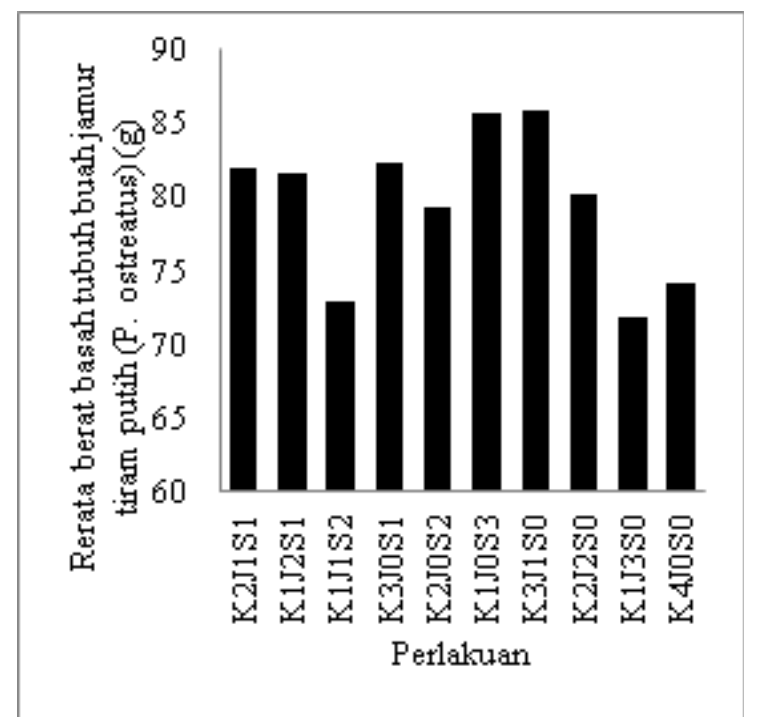

Gambar 2. Rerata berat basah tubuh buah jamur tiram putih (P. ostreatus)

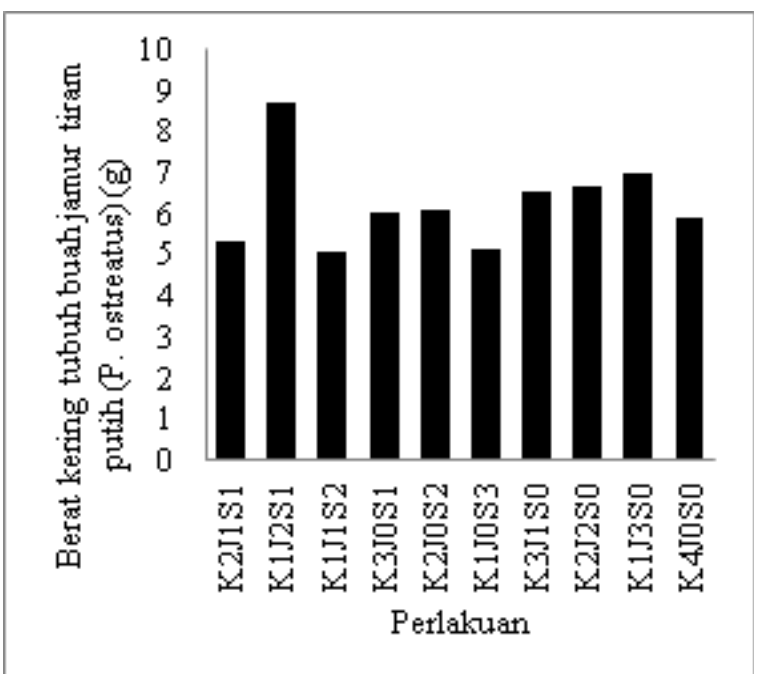

Gambar 3. Rerata berat kering tubuh buah jamur tiram putih (P. ostreatus)
Menurut Pathmashini et al. (2008), ukuran partikel yang lebih sederhana lebih mudah diserap sebagai nutrisi bagi pertumbuhan miselium dan tubuh buah jamur. Amuneke et al. (2011), menyatakan bahwa jamur tiram membutuhkan makanan dalam bentuk molekul selulosa dan pati dalam bentuk yang paling sederhana. Pokhrel et al. (2013), menambahkan bahwa substrat yang memiliki kandungan lignin dan selulosa tinggi dapat membutuhkan waktu lebih lama untuk memulai terbentuknya pinhead dan pembentukan tubuh buah.

Ukuran partikel yang lebih sederhana dapat terserap oleh hifa yang merupakan bentuk tubuh jamur. Hifa jamur dapat tumbuh di dalam substratnya. Hifa jamur mengandung enzim ekstraseluler yang dapat memecah makromolekul seperti selulosa, hemiselulosa, lignin dan protein, menjadi molekul sederhana yang dapat diserap oleh sel jamur tersebut. Pertumbuhan hifa yang semakin banyak akan membentuk miselium. Menurut Suparti dan Marfuah, (2015), kemampuan jamur mendegradasi lignin disebabkan oleh adanya enzim ekstraseluler yang disekresikan oleh jamur. Hifa jamur dapat tumbuh pada permukaan substrat yang mengandung lignin sehingga melalui kekuatan eksoenzim yang dihasilkan oleh jamur akan menimbulkan zona lisis di sekitar media. Carrasco et al. (2018), menyatakan bahwa produksi enzim pendegradasi lignin (lakase, lignin peroksidase, mangan peroksidase atau quinon reduktase), dan enzim pendegradasi hemiselulosa dan selulosa (xylanase, selulase atau selobiosa dehidrogenase) menyebabkan hidrolisis makromolekul selulosa, hemiselulosa dan lignin pada substrat, sehingga penting untuk pertumbuhan jamur.

Hasil analisis statistik secara ANOVA menunjukkan bahwa media serbuk kayu dengan penambahan sekam padi dan jerami padi tidak berbeda nyata terhadap pertumbuhan miselium dan berat basah tubuh buah jamur tiram putih ( $P$. ostreatus). Hal ini karena sekam padi dan jerami padi juga mengandung selulosa dan lignin yang dibutuhkan untuk pertumbuhan jamur tiram 
putih. Selain itu juga terdapat pada serbuk kayu. Dari ketiga bahan tersebut digunakan sebagai tambahan komposisi media tanam jamur karena mengandung senyawa yang dibutuhkan untuk menunjang pertumbuhan jamur, diantaranya selulosa, lignin dan hemiselulosa. Menurut Yanuartono et al. (2017) dan Pratiwi et al. (2016), jerami padi mengandung $37,71 \%$ selulosa; $21,99 \%$ hemiselulosa; dan $16,62 \%$ lignin. Kandungan nutrisi dalam $100 \mathrm{~g}$ sekam padi terdiri dari 33-44\% selulosa, 19- $47 \%$ lignin, 17-26\% hemiselulosa dan silika 13\% (Naufala dan Pandebesie, 2015).

Berdasarkan hasil penelitian yang diperoleh semakin besar berat basah tubuh buah jamur tidak menjamin berat keringnya semakin tingi. Selama proses pengeringan tubuh buah jamur, maka akan kehilangan kadar air. Proses pengeringan yang sempurna akan menghilangkan persentase kadar air akibat pengeringan. Menurut Astuti dan Kuswytasari (2013), saat tubuh buah jamur dihilangkan kadar airnya, tubuh buah jamur masih tetap memiliki massa.

Tubuh buah jamur tiram putih (P. ostreatus) memiliki kandungan air tinggi. Hampir semua jenis tubuh buah jamur segar memiliki kandungan air sebanyak $85-95 \%$ sedangkan pada jamur yang sudah dikeringkan hanya mengandung 5-20\% (Saidu dan Yuzir, 2011). Perlakuan media tanam jamur tiram yang berupa serbuk kayu, sekam padi dan jerami padi dengan berbagai perbandingan dapat digunakan sebagai tempat tumbuhnya miselium dan tubuh buah jamur tiram putih sehingga dapat menguraikan dan memanfaatkan komponen nutrisi yang ada di dalam media sebagai sumber nutrisinya. Miselium jamur tiram putih menyerap nutrisi dari media dalam baglog yang sudah terlarut dalam air. Nutrisi tersebut digunakan untuk proses metabolisme sehingga miselium dapat membentuk pinhead dan tubuh buah. Sebagian besar tubuh jamur mengandung air. Akan tetapi jamur juga banyak mengandung nutrisi dan serat selain mineral dan kadar air yang membuat jamur memiliki massa apabila telah dikeringkan. Menurut Amalia et al., (2018) menyatakan bahwa pertumbuhan tubuh buah jamur dipengaruhi dari penyerapan unsur hara. Penyerapan unsur hara dapat berpengaruh terhadap diameter batang, diameter tubuh buah jamur dan berat segar jamur.

Kelembaban optimum yang dibutuhkan untuk budidaya jamur tiram putih (P. ostreatus) pada penelitian ini yaitu berkisar 65-95\% dengan suhu rata-rata $25-30^{\circ} \mathrm{C}$. Kelembapan udara berpengaruh pada pertumbuhan jamur tiram, cepat atau lambatnya pertumbuhan miselum dan tubuh buahnya. Kelembapan memegang peranan penting, karena pada pembentukkan tubuh buah, membutuhkan kelembapan sebesar 90-95\% dengan suhu $21-28^{\circ} \mathrm{C}$. Sedangkan saat kemunculan pinhead dibutuhkan kelembapan udara sebesar 90-100 \%dengan suhu berkisar $21-27^{\circ} \mathrm{C}$ (Widyastuti dan Tjokrokusumo, 2008). Meskipun demikian, pertumbuhan jamur tiram cukup toleran terhadap kelembapan hingga 70 \%. Pada kisaran tersebut miselium dan tubuh buah dapat sama-sama hidup, tumbuh, dan berkembang, namun pengaruhnya terhadap kecepatan tumbuh dan kualitas yang dihasilkan. Selanjutnya menurut Ashraf et al. (2013), terdapat banyak faktor yang dapat mempengaruhi hasil budidaya jamur tiram putih (P. ostreatus), yaitu tingkat kelembaban pengomposan dan fluktuasi suhu. Selain itu, ketika $\mathrm{pH}$, tingkat kelembaban dan rasio $\mathrm{C} / \mathrm{N}$ terdapat dalam komposisi media yang terbaik maka jumlah pinhead dan tubuh buah jamur terbentuk maksimal.

\section{Simpulan}

Miselium jamur tiram putih (P. ostreatus) dapat tumbuh pada media campuran serbuk kayu, sekam padi dan jerami padi. Pertumbuhan optimal terdapat pada perlakuan K1J2S1 dengan rerata kecepatan pertumbuhan sebesar 30,60 $\mathrm{cm} / 30$ hari. Rerata berat basah tubuh buah jamur tiram ( $P$. ostreatus) tertinggi terdapat pada perlakuan K3J1S0 yaitu sebesar 85,83 g sedangkan rata-rata berat basah terendah terdapat pada perlakuan K1J3S0 yaitu sebesar 71,85 g. Rerata berat kering tubuh buah jamur tiram (P. ostreatus) tertinggi terdapat pada perlakuan K1J2S1 yaitu sebesar 8,71 g sedangkan terendah terdapat pada perlakuan K1J1S2 yaitu sebesar $5,09 \mathrm{~g}$. 
Ucapan Terima Kasih

Penulis mengucapkan terima kasih kepada Kementerian Riset, Teknologi dan Pendidikan
Tinggi, Direktorat Jenderal Penguatan Riset dan Pengembangan yang telah memberikan dana penelitian bersumber dari Hibah Penelitian Dosen Pemula Tahun Pendanaan 2018.

\section{Daftar Pustaka}

Amalia, L., Budiasih, R., \& Samsul, A. (2018). Pengaruh posisi bukaan plastik baglog dan konsentrasi pupuk fosfor terhadap pertumbuhan dan hasil jamur tiram putih (Pleurotus ostreatus). Kultivasi, 17(1). Retrieved from http://jurnal.unpad.ac.id/kultivasi/article/view/16075

Amuneke, E. H., Dike, K. S., \& Ogbulie, J. N. (2011). Cultivation of Pleurotus ostreatus : An edible mushroom from agro base waste products. J. Microbiol. Biotech. Res., 1(3), 1-14.

Ashraf, J., Ali, M. A., Ahmad, W., Ayyub, C. M., \& Shafi, J. (2013). Effect of Different Substrate Supplements on Oyster Mushroom (Pleurotus spp.) Production. Food Science and Technology, 1(3), 44-51. https://doi.org/10.13189/FST.2013.010302

Astuti, H., Astuti, H. K., \& Kuswytasari, N. D. (2013). Efektifitas Pertumbuhan Jamur Tiram Putih (Pleurotus ostreatus) dengan Variasi Media Kayu Sengon (Paraserianthes falcataria) dan Sabut Kelapa (Cocos nucifera). Jurnal Sains Dan Seni ITS, 2(2), E144-E148. https://doi. org/10.12962/j23373520.v2i2.3955

Carrasco, J., Zied, D. C., Pardo, J. E., Preston, G. M., \& Pardo-Giménez, A. (2018). Supplementation in mushroom crops and its impact on yield and quality. AMB Express, 8(1), 146. https://doi. org/10.1186/s13568-018-0678-0

Egra, S., Kusuma, I. W., \& Arung, E. T. (2018). Kandungan Antioksidan pada Jamur Tiram Putih (Pleurotus ostreatus). ULIN: Jurnal Hutan Tropis, 2(2). https://doi.org/10.32522/u-jht. v2i2.1549

Facchini, J. M., Alves, E. P., Aguilera, C., Gern, R. M. M., Silveira, M. L. L., Wisbeck, E., \& Furlan, S. A. (2014). Antitumor activity of Pleurotus ostreatus polysaccharide fractions on Ehrlich tumor and Sarcoma 180. International Journal of Biological Macromolecules, 68, 72 77. https://doi.org/10.1016/J.IJBIOMAC.2014.04.033

Farhatul Wahidah, B., \& Adi Saputra, F. (2015). Perbedaan Pengaruh Media Tanam Serbuk Gergaji dan Jerami Padi Terhadap Pertumbuhan Jamur Tiram Putih (Pleurotus ostreatus). Biogenesis: Jurnal Ilmiah Biologi, 3(1), 11-15. https://doi.org/10.24252/bio.v3i1.560

Hearst, R., Nelson, D., McCollum, G., Millar, B. C., Maeda, Y., Goldsmith, C. E., ... Moore, J. E. (2009). An examination of antibacterial and antifungal properties of constituents of Shiitake (Lentinula edodes) and Oyster (Pleurotus ostreatus) mushrooms. Complementary Therapies in Clinical Practice, 15(1), 5-7. https://doi.org/10.1016/J.CTCP.2008.10.002

Jayakumar, T., Thomas, P. A., Sheu, J. R., \& Geraldine, P. (2011). In-vitro and in-vivo antioxidant effects of the oyster mushroom Pleurotus ostreatus. Food Research International, 44(4), 851861. https://doi.org/10.1016/J.FOODRES.2011.03.015

Kalyan, N., \& Yadav, K. P. (2013). Cultivation of Pleurotus sajor-caju using different agricultural residues. International Journal of Agricultural Policy and Research, 1(2), 19-23.

Naufala, W. A., \& Pandebesie, E. S. (2016). Hidrolisis Eceng Gondok dan Sekam Padi untuk Menghasilkan Gula Reduksi sebagai Tahap Awal Produksi Bioetanol. Jurnal Teknik ITS, 4(2), B109-B113. https://doi.org/10.12962/J23373539.V4I2.11308 
Obodai, M., Cleland-Okine, J., \& Vowotor, K. A. (2003). Comparative study on the growth and yield of Pleurotus ostreatus mushroom on different lignocellulosic by-products. Journal of Industrial Microbiology \& Biotechnology, 30(3), 146-149. https://doi.org/10.1007/s10295002-0021-1

Pathmashini, L., Arulnandhy, V., \& Wijeratnam, R. W. (2009). Cultivation of Oyster Mushroom (Pleurotus ostreatus) on Sawdust. Ceylon Journal of Science (Biological Sciences), 37(2), 177. https://doi.org/10.4038/cjsbs.v37i2.505

Pratiwi, R., Rahayu, D., \& Barliana, M. I. (2016). Pemanfaatan Selulosa Dari Limbah Jerami Padi (Oryza sativa) Sebagai Bahan Bioplastik. Indonesian Journal of Pharmaceutical Science and Technology, 3(3), 83. https://doi.org/10.15416/ijpst.v3i3.9406

Pugeg Arya, I. N., Kusmaninga, S., Sutjiatmo, A. B., Sumartini, Y., Nursidah, A., \& Narvikasar, S. (2010). The Effect of Laetiporus sp. (Bull. ex Fr.) Bond. et Sing. (Polyporaceae) Extract on Total Blood Cholesterol Level. Biotechnology(Faisalabad), 9(3), 312-318. https://doi. org/10.3923/biotech.2010.312.318

Saidu, M., Salim, M., \& Yuzir, M. (2011). Cultivation of oyster mushroom (Pleurotus spp.) on palm oil mesocarp fibre. AFRICAN JOURNAL OF BIOTECHNOLOGY, 10(71), 1597315976. https://doi.org/10.5897/AJB11.1942

Sharma, S., Yadav, R. K. P., \& Pokhrel, C. P. (2013). Growth and Yield of Oyster mushroom ( Pleurotus ostreatus ) on different substrates. Journal on New Biological Reports, 2(1), 3-8.

Sipahutar, D. (2010). Teknologi Briket Sekam Padi. Riau: Balai Pengkajian Teknologi Pertanian (BPTP).

Suparti, S., \& Marfuah, L. (2015). Produktivitas Jamur Tiramputih (Pleurotus ostreatus) Pada Media Limbah Sekam Padi dan Daun Pisang Kering Sebagai Media Alternatif. Bioeksperimen: Jurnal Penelitian Biologi, 1(2), 37-44.

Widiwurjani. (2010). Menggali potensi seresah sebagai media tumbuh jamur tiram putih. Surabaya: Unesa University Press.

Widyastuti, N. (2008). Aspek Lingkungan Sebagai Faktor Penentu Keberhasilan Budidaya Jamur Tiram (Pleurotus sp.). Jurnal Teknologi Lingkungan, 9(3). https://doi.org/10.29122/jtl. v9i3.473

Wu, J.-Y., Chen, C.-H., Chang, W.-H., Chung, K.-T., Liu, Y.-W., Lu, F.-J., \& Chen, C.-H. (2011). Anti-Cancer Effects of Protein Extracts from Calvatia lilacina, Pleurotus ostreatus and Volvariella volvacea. Evidence-Based Complementary and Alternative Medicine: ECAM, 2011, 982368. https://doi.org/10.1093/ecam/neq057

Yanuartono, Y., Purnamaningsih, H., Indarjulianto, S., \& Nururrozi, A. (2017). Potensi jerami sebagai pakan ternak ruminansia. Jurnal Ilmu-Ilmu Peternakan, 27(1), 40-62. https://doi. org/10.21776/ub.jiip.2017.027.01.05 